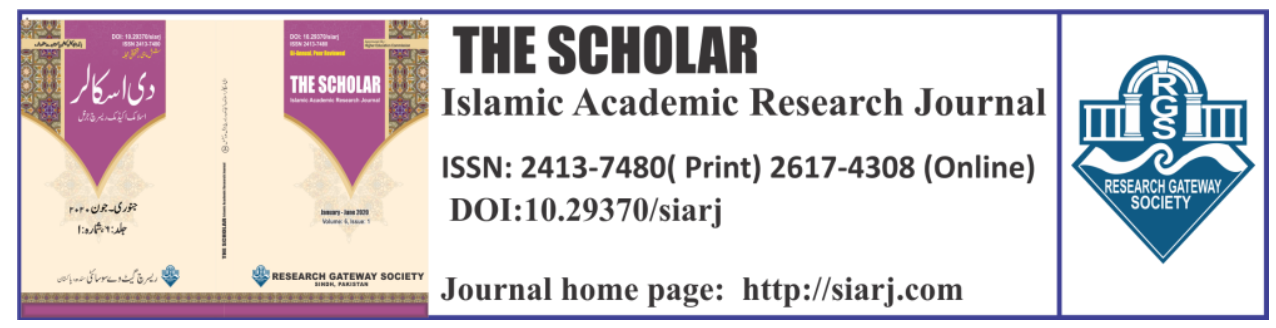

\title{
A STUDY TO EXPLORE THE ROLE OF LEADERSHIP IN ISLAMIC PERSPECTIVE
}

\section{Mubashira Khalid}

Assistant Professor of Education, IER University of the Punjab Lahore, Pakistan.

Email: mubashirakhalid@yahoo.com

ORCID ID:

http://orcid.org/0000-0003-0856-7477

\section{Muhammad Faisal Farid}

Assistant Professor University of Education Faisalabad. Pakistan.

Email: dr.faisal.farid@ue.edu.pk

ORCID ID: http://orcid.org/0000_0001_7684_5294

To cite this article:

Khalid Mubashira, Aroona Hashmi and Muhammad Faisal Farid. "A STUDY TO EXPLORE THE ROLE OF LEADERSHIP IN ISLAMIC PERSPECTIVE "The ScholarIslamic Academic Research Journal 6, No. 2 (Dec 30, 2020):86-109.

To link to this article: https://doi.org/10.29370/siarj/issue11ar4

Journal

Publisher

DOI:

URL:

License:

Journal homepage

Published online:

\section{Aroona Hashmi}

Assistant Professor of Education, IER University of the Punjab Lahore, Pakistan.

Email:aroonahashmi@gmail.com

ORCID ID:

https://orcid.org/0000-0002-6810-2594
The Scholar Islamic Academic Research Journal

Vol. 6, No. 2 ||July-December 2020 ||P. 86-109

Research Gateway Society

10.29370/siarj/issue11ar4

https://doi.org/10.29370/siarj/issue11ar4

Copyright c 2017 NC-SA 4.0

www.siari.com

2020-12-30
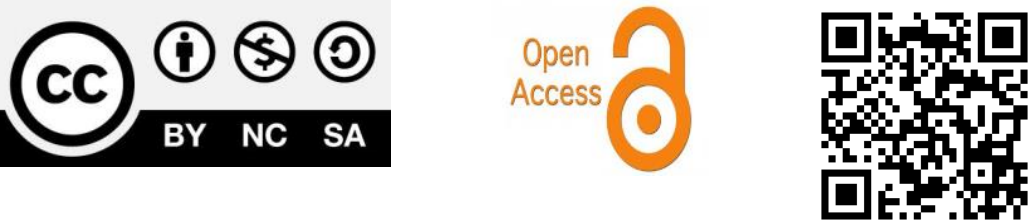


\title{
A STUDY TO EXPLORE THE ROLE OF LEADERSHIP IN ISLAMIC PERSPECTIVE
}

\author{
Syed Mubashira Khalid, Aroona Hashmi, Muhammad Faisal Farid
}

\begin{abstract}
:
The role of leaders is admitted worldwide. The leader leads the follower toward the right path. A single person may change the destiny of the nation on the basis of God gifted abilities and intellect. In Islam, the leader is equipped with countless blessings from Almighty Allah. He is the perfect role model and gets the crown of Vicegerent on earth. In the rest of the world, the leader has his own prestige and grandeur on the basis of efforts he makes for his country. Alexander said, 'I will not terrify if lions' army led by a sheep; I will frighten if sheep's army led by a lion'. In this paper, the role of leadership in the light of Quran and Sunnah is discussed. It is the need of the hour to abide by divine laws if we want to restore the role of Vicegerent on earth. All the solution of social, political, family, and professional problems lies in the true practices of Islamic Leadership.
\end{abstract}

KEYWORDS: Islamic Leadership, Quran Teaching, Sunnah of Prophet INTRODUCTION:

Leadership is a person's ability to lead individuals to complete certain goals, train their followers with chain of Management tasks in a flawless environment. Great leaders are always men of principles with effective 
communication, determination and dynamic personalities. ${ }^{1}$

\section{ISLAMIC CONCEPT OF LEADERSHIP}

The Islamic doctrine comprises some beliefs a person holds as a Muslim. The basis of principle is the oneness of God (Touheed). The Muslims have firm belief in angels, the messengers, the revealed books, hereafter and the day of judgement for human beings. ${ }^{2},{ }^{3}$

There are many Arabic words used for leaders. An Amir is interpreted as a prince, derive from word Amara that means order. Amir is also used for commander. Many evidences revealed when Muslim groups went on mission, they used to select an Amir for group members to lead. ${ }^{4}$ The second word for leader is Khalifa derived from word khalafa means success. The Khalifa denote a vicegerent or successor. This word Khalifa used two times in Holy Quran to mention a vicegerent on the occasion of conversation between Angels and God about Hazrat Adam's creation:

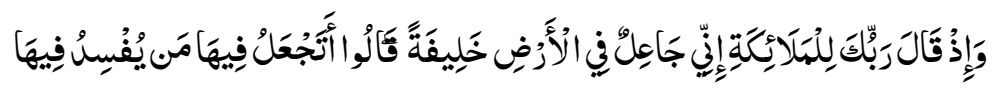

"Remember when thy Lord told Angels, 'I will create a vicegerent for earth'. 5 (Al-Baqrah-2, v-30].

The other time, it was used for Prophet David:

${ }^{1}$ Jamil, M. Y. Islamic Perspective of Leadership: A Role Model for Today's CEOs. Journal of Islamic Thought and Civilization, 5No. 11(2015): 23-55.

${ }^{2}$ Esposito, J. L. What everyone needs to know about Islam. New York: Oxford University. (2002).

${ }^{3}$ Shaltout, M. Islam: Creed and Law. Cairo: Shorouk International. (2004).

${ }^{4}$ Haddara, M., \& Enanny, F. Leadership: An Islamic Perspective. Faculty of Education of Memorial University of Newfoundland. (2009).

${ }^{5}$ Al-Quran (2):30. 


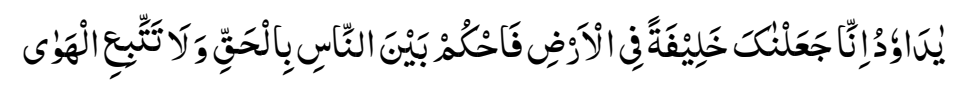

“O' Daoud (David), We have selected you Khalifa (vicegerent) for earth. Rule people with utmost justice and don't follow your wishes ${ }^{6}$ (Surah Sad38, v-26). The word "Khilafa" is substitute for khalifa. ${ }^{7}$

\section{REVIEW OF RELATED LITERATURE:}

The third word that is used in Islam for leader is Imam. It originates from word Amma means face toward. Imam leads the people in prayer. The word "Imam" has religious implications, the Khalifa or Amir is not certainly religious leaders. Imam indicates to provide religious guidance to society, but Khalifa and Amir mean govern and command. ${ }^{8}$

The Holy Book, Quran produces solid acclamations for potential reflection among leaders in its true spirit. Our blessed Holy Prophet Muhammad (PBUH), served as chief executive, head of state, judicial head, commander in chief and mentor of His Sahaba during His stay at Madina for ten years. ${ }^{9}$

With Holy Prophet SAW's utmost abilities, the small state of Madina became the center of excellence for Ansars and Muhgireen into a world's most civilized destiny. ${ }^{10}$

\footnotetext{
${ }^{6}$ Al-Quran (38):26.

${ }^{7}$ Haddara, M., \& Enanny, F. Leadership: An Islamic Perspective. Faculty of Education of Memorial University of Newfoundland. (2009). ${ }^{8}$ ibid

${ }^{9}$ Jamil, M. Y. Islamic Perspective of Leadership: A Role Model for Today's CEOs. Journal of Islamic Thought and Civilization, 5No. 11(2015): 23-55.

${ }^{10}$ Jamil, M. Y. Islamic Perspective of Leadership: A Role Model for Today's CEOs. Journal of Islamic Thought and Civilization, 5No. 11(2015): 23-55.
} 
There are many universal traits like communication skills, self-reliance, compassion, trustworthiness, inspiration, awareness and foresightedness commonly be seen among successful Leaders. Allah SWT considered Prophet Muhammad (PBUH) in the Quran:

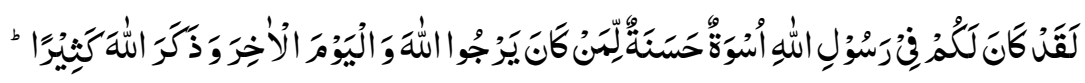

No doubt there is a model for you in Allah's Messenger's life for those whose have faith in Allah and eternal Day and [who] reminds Allah often11 (Al-Ahzab-33, V 21)

The best qualities of Leadership were observed in the lives of our Holy Prophet (PBUH) and His (Sihabas), these are; 1. Motivating people

2. Sympathy and affectionateness for followers

3. Faith

4. High Self-esteem.

5. Open for recommendations

6. Awareness of accountability

7. Unbiasedness

8. Immediate decision powers

9. Empathize with unprivileged people

10. Effective Communication

11. Kind hearted

12. Self-motivation

13. Long-term planners

${ }^{11}$ Al-Quran (33):21. 
A great part of qualities of Islamic leadership derived from two bases, the Al-Quran and Sunnah. It is admitted fact that Islam exerted a vital role in Muslims' lives. The Muslim Leaders have significant ethical and administrative influence. Leadership is defined as "the competence to stimulate sustenance and self-assurance amongst people wanted to achieve structural goals.

The concept of leadership is as old as mankind. ${ }^{12}$ In view point of. ${ }^{13}$ the leadership is the talent to make inspiration, support and confidence among individuals who need to accomplish administrative goals. Yukl14 revealed that leadership is the method to influence people to approve and understand the problems and to solve them. It is the process of facilitating individuals toward collective efforts and shared objectives. There are three sources of Islamic leadership the Quran, the Sunnah of Messenger (SAW), and biography of Muslim leaders, and the Islamic literature on leadership. The development of leadership from Islamic point of view into conventional is credible broad sympathetic leadership behavior. ${ }^{15}$ TRADITIONAL LEADERSHIP APPROACHES:

According to Yukl16 there are trait approach, the behavior approaches,

${ }^{12}$ Haddara, M., \& Enanny, F. Leadership: An Islamic Perspective. Faculty of Education of Memorial University of Newfoundland. (2009).

${ }^{13}$ Dubrin, A. J. Leadership. (5th Ed.). New York: Houghton Mifflin. (2007).

${ }^{14}$ Yukl, G. Leadership in organizations (6th ed.). Upper Saddle River, NJ: Pearson Prentice Hall. (2006).

${ }^{15}$ Jamil, M. Y. Islamic Perspective of Leadership: A Role Model for Today's CEOs. Journal of Islamic Thought and Civilization, 5No. 11(2015): 23-55.

${ }^{16}$ Yukl, G. Leadership in organizations (6th ed.). Upper Saddle River, NJ: Pearson Prentice Hall. (2006). 
situational, the approach of power-influence, and integrative approaches of leadership. The ancient approach is the trait approach to study leadership in early twentieth century. It assumes that some people have innate traits blessed to successful leaders. The behavioral theory occurred in late 1940s. It attempted to answer two questions theory. Why persons not possessing traits become successful leaders and vice versa. Those studies change the behavioral approach to study the behavior of leaders rather than traits. The basic theme of behavioral approach was that leaders are not born and can be made.

The critical analysis of trait and behavioral approaches ignored the effects of situational aspects on leadership styles. The situational theory of leadership began during 1960. It emphasizes the existence of situational variables like work type, leader authority and environmental aspects. According to 17 the leader should have power to exert influence. The types of powers: coercive, reward, referent, legitimate, and expert. The integrative approach was considered the effect of situational circumstances on followers' characteristics. The environmental factors play a significant role among subordinates' performance. ${ }^{18,19}$

${ }^{17}$ Dubrin, A. J. Leadership. (5th Ed.). New York: Houghton Mifflin. (2007).

${ }^{18}$ Pike, H., Hills, A. and MacLennan. Personality and military leadership. Prepared for Canadian Forces Leadership Institute. (2002).

${ }^{19}$ Smithers, S., Livingstone, H., and Nadjiwon-Foster, M. Personality \& Military Leadership. Canadian Forces Leadership Institute. (2002). 


\section{A Study to Explore the Role of Leadership in Islamic Perspective}

The studies about behavior of leaders on effectiveness were prominent during 1950 to mid of 1980. There were two major studies, Michigan Leadership Studies and Ohio State Studies of Leadership. ${ }^{20}$ The Studies at Ohio State explored two dimensions as 'consideration' and 'initiating structure' that were responsible for eighty-five percent leadership behaviors.21 Michigan Studies on Leadership discovered three leadership behaviors from ineffective to effective leaders, relations-oriented, taskoriented and participative behaviors of leadership. ${ }^{22}$

\section{THE LEADERSHIP NATURE IN ISLAM:}

The Islamic perspective, leadership means to lead a state or organization toward the attainment and realization of common goals to create a uniform system of ease, contentment and success for its inhibitors.23 In Islam, leadership is reflected as trustworthy. A leader is faithful for leading subordinates to manage and organize. The leaders also possess teaching abilities and reflect themselves as role model in their practical life. They also have an impact on their learners and followers 24 . The accountability and trust go side by side. Two aspects of accountability and trust. A leader

${ }^{20}$ Yukl, G. Leadership in organizations (6th ed.). Upper Saddle River, NJ: Pearson Prentice Hall. (2006).

${ }^{21}$ Dubrin, A. J. Leadership. (5th Ed.). New York: Houghton Mifflin. (2007).

${ }^{22}$ Yukl, G. Leadership in organizations (6th ed.). Upper Saddle River, NJ: Pearson Prentice Hall. (2006).

${ }^{23}$ Jamil, M. Y. Islamic Perspective of Leadership: A Role Model for Today's CEOs. Journal of Islamic Thought and Civilization, 5, No. 11(2015): 23-55.

${ }^{24}$ Shah, M. Anees-ul-Husnain, Asif Iqbal, and Muhammad Shabbir Ali. "A study of religious role of teachers and its relationship with students' religious practices." The Scholar-Islamic Academic Research Journal 6, No. 1 (2020): 115-134. 


\section{A Study to Explore the Role of Leadership in Islamic Perspective}

is held accountable to Allah and entrusted by God for trust. The leader is also accountable to people.25 Almighty Allah SWT revealed in Quran, 'Adam was created for vicegerent on earth, note that occasion, when your Lord said to angels: I am going to make a vicegerent on earth'26 [2:30]. To complete leadership role, Adam accepted the trust on earth 'the fact is We offered the Trust to the heavens, to the earth and to the mountains, but they refused to undertake it and were afraid, but man undertook it. He was indeed unjust and ignorant'27 [33:72]. To permit Adam and his children to accomplish this trust, Allah bestowed capability to learn, 'He taught Adam the names of all'28 [2:31] and He bestowed message to make able for maintain fairness on earth29 [57:25]. The vicegerence of Adam is trust on earth.

A well-known visionary belief outlined the concept of multi-level leadership. The Holy Prophet (PBUH) said, 'Every one among you is a guardian and is accountable for his people'30 (Muslim, 2000, 663). The ruler who held authority on people should perform like a guardian. A person is custodian of family, woman is guardian for her house, and a servant for his owner's property.

\section{RESPONSIBILITIES OF MUSLIM LEADER ACCOUNTABILITY:}

A leader is required to execute Allah's obligations in accordance to His

${ }^{25}$ Haddara, M., and Enanny, F. Leadership: An Islamic Perspective. Faculty of Education of Memorial University of Newfoundland. (2009).

${ }^{26}$ Al-Quran (2):30.

${ }^{27}$ Al-Quran (33):72.

${ }^{28}$ Al-Quran (2):31.

${ }^{29}$ Al-Quran (57):25.

${ }^{30}$ Muslim (2000). Sahih Muslim 


\section{A Study to Explore the Role of Leadership in Islamic Perspective}

will. The characteristics like trust, accountability, responsibility, Amanah, Taklif are perceived as innate attributes in a leader. The leader is the most imperious member in every organization. These prominent qualities leadership embraced in religion of Islam and described and examined by Great Prophets of Almighty Allah SWT. ${ }^{31}$

First of all, a leader is held accountable to Allah SWT and then to his public. The accountability to people is linked with accountability to Allah SWT. The Quran states:

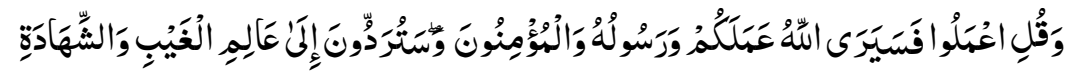

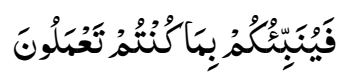

And say, "do for Allah sees your actions, and His Prophet and followers. And you will return to Knower of hidden and seen, and He will tell you about your deeds."32 (Surah Tawbah, verse 105)

The Quranic verse clearly exposes the clear link between accountability to people and Allah SWT. Accountability is more highlighted in the Holy Quran33 (Surat- Bany-Israeel, verse, 13-14): 'every man has fate, we fastened to neck: on Judgement Day We provide him a document that spreads wide. Read your document! You will avail the day as a permanent reckoner beside you34 (Surah Al-Israa, verse, 13-14). ${ }^{35}$

${ }^{31}$ Jamil, M. Y. Islamic Perspective of Leadership: A Role Model for Today's CEOs. Journal of Islamic Thought and Civilization, 5No. 11(2015): 23-55.

${ }^{32}$ Surah Tawbah, verse 105

${ }^{33}$ Surat- Bany-Israeel, verse, 13-14

${ }^{34}$ Surah Al-Israa, verse, 13-14

${ }^{35}$ Abdallah, A., Citaku, F., Waldrop, M., Zillioux, D., Citaku, L. P., \& Khan, Y. H. A review of Islamic perspectives on leadership. 


\section{A Study to Explore the Role of Leadership in Islamic Perspective}

\section{COLLECTIVE RESPONSIBILITY:}

Leadership is a collective responsibility ${ }^{36}$ In Islam duties are made collectively or individually. To fulfil personal duty is the motto of every Muslim. They include deeds of worship, fasting and prayers. A collective duty can be fulfilled in groups who voluntarily perform on behalf of the community. Since, to lead the people toward the right path, it is considered as collective duty of Ummah to perform. ${ }^{37}$

\section{QURAN MENTIONS LEADERSHIP:}

There is specimen of leadership qualities in the Quran by giving two examples. The queen of Saba for good leadership, while the Pharaoh of Egypt for bad leadership. The Quran praises the way of Queen Saba controlled the attack postured by Prophet Suliman's (AS) Army. She provided information to her officers. They claimed they will fight against Suliman's (AS) army and predicted to won the war easily, she corrected they were unaware about the strength of Suliman's (AS) army. She sensibly suggested to get further information. Her timely actions and wise decision saved her army and country from a serious disaster.

On opposite side, the Pharaoh of Egypt was uninterested to get honest advice from subordinates. He proudly made his own decision and claimed that, "I want to make you see what I see myself; I am guiding you along the right path.” [40:29]

\section{CONSULTATION:}

International Journal of Scientific Research and Management (IJSRM), 7No.11(2019): 574-578.

${ }^{36}$ Ibn-e-Khaldoon. Al-Muqaddimah [The Introduction]. Cairo, Egypt: Dar El-Shaab. (1377).

${ }^{37}$ Hawwa, S. Al-Rasool [The Messenger]. Cairo, Egypt: Dar Al-Salam. (1990). 
A Study to Explore the Role of Leadership in Islamic Perspective

The tales mentioned in Quran indicated the importance of consultancy is imperious for effective leadership. The leader should infer the given advice wisely. This code was repeated in Quranic verse that addressed the Messenger (PBUH):

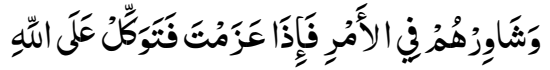

"Consult them in the conduct of affairs, but when you make a resolution then be firm in implementing your resolution and put your trust in God"38 (Al-Imran-3, v-159). It is evident that an effective leader should consult his subordinates to achieve desired objectives.

\section{SELECTION OF RIGHT COMPANIONS:}

The Holy Quran indicated the importance of consultation is vital for effective leadership decisions. This principle is stated in a verse while addressing the Prophet, "Consult them in the conduct of affairs, but when you make a resolution then be firm in implementing your resolution and put your trust in Allah"39. The second point of right leader's choice was Consensus (ijma). It was followed at the death of the Holy prophet (PBUH). All Sihabas gathered at the Saqifah banu Saad for selection of caliph. The majority decided Hazrat Abu Bakr and assure loyalty to him. Hazrat Abu Bakr was chosen as Muslim Caliph by consensus.

\section{CONSIDERATION:}

The Holy Quran mentions the reputation of keeping leaders' consideration. 'with the mercy of Almighty Allah (SWT), you become sympathetic with

\footnotetext{
38 Al-Quran (3): 159.
}

39 Al-Quran (3): 159. 
The Scholar Islamic Academic Research Journal

Vol. 6, No. 2 || July -December 2020 || P. 86-109

https://doi.org/10.29370/siarj/issue11ar4

them, you were rough and tough heart, they would assuredly restrained you $^{40}$ (Surah Al-Imran, verse, 159). According to Quran, it clearly demonstrates the importance of consideration of leadership effectiveness. Without it, the leader is unable to attain organizational goals. ${ }^{41}$ The Holy Quran acclaims noble and self-sacrificing persons:

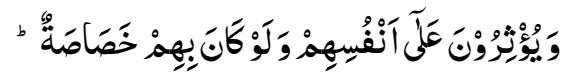

'And gave them priority over their selves, even they have their selfneed' ${ }^{42}$.

\section{INITIATING STRUCTURE:}

The planning process, setting up goals, coordinate work activities are dominant in the Quran. The example is the incident of birth of universe and teaching of Prophet Adam and Eve for earth mission. God created Hazrat Adam from mud and exhaled His spirit in Adam. Allah SWT taught Adam different names of things and blessed Adam ability of acquired knowledge for making wise decisions. Almighty Allah SWT said angels to tell names. The angels modestly accepted their bounds and accredited Allah's Bounties on Hazrat Adam. Allah ordered the Satan and angels and to bow in respect for new creation. The angels accepted and bowed but Satan become proud and rejected. The act of Satan rebellion stemmed in ejection from Almighty Allah's grace.

40 Al-Quran (3): 159.

${ }^{41}$ Haddara, M., and Enanny, F. Leadership: An Islamic Perspective. Faculty of Education of Memorial University of Newfoundland. (2009).

${ }^{42}$ Abdallah, et al. A review of Islamic perspectives on leadership. International Journal of Scientific Research and Management (IJSRM), 7No.11(2019): 574-578. 
The Scholar Islamic Academic Research Journal

Vol. 6, No. 2 || July -December 2020 || P. 86-109

https://doi.org/10.29370/siarj/issue11ar4

The Satan demanded that Allah give him time till Judgment Day and swore that he try to temptation of human beings to lure from straight path. The Quran revealed that Satan had no power and control on people. 'Certainly, (the Satan) has no control over my people. ${ }^{43}$ (17:65).

\section{PLANNING AND ORGANIZING:}

The example regarding planning and organizing as inferred in Quran about the miracle planning and state arrangement designed by Prophet Joseph's (AS). He planned to tackle the Egypt from draught by his vision and intellect so that Egyptian state becomes helper for neighboring countries in the state draught ${ }^{44}(12: 46-49)$

\section{CONSULTATION:}

According to Islamic viewpoint, consultation is a basic concept of leadership. Consultation is stated two times in $\operatorname{Quran}^{45}$ (3:159). It also defined an obligatory liability must be assumed by believers like paying dues and saying prayers. The Quran says, 'who answers the voice of Lord, perform prayer, manages the shared discussion, and arrange food that we bestowed $^{46}$ (Surah Ash-Shuraa, verse, 38).

\section{TYPES OF LEADERSHIP; SERVANT LEADERSHIP:}

Islam has endorsed the idea of servant leadership. This idea is derived from Prophet sayings, "a leader is the servant of people. ${ }^{47}$ The Prophetic

\footnotetext{
${ }^{43}$ Haddara, M., and Enanny, F. Leadership: An Islamic Perspective. Faculty of Education of Memorial University of Newfoundland. (2009).

${ }^{44}$ Surah Al-Yousaf, v, 46-49.

${ }^{45}$ Al-Imran-3, v-159

${ }^{46}$ Surah Ash-Shuraa, verse 38

${ }^{47}$ Beekun, R. I. and Badawi, J. Leadership: An Islamic perspective. Beltsville, MD: Amana. (1999).
} 
The Scholar Islamic Academic Research Journal

Vol. 6, No. 2 || July -December 2020 || P. 86-109

https://doi.org/10.29370/siarj/issue11ar4

customs highlight the reputation of utilization of honesty among leaders when they serve their subordinates ${ }^{48}$ (Imam Muslim, 2000). The Quran orders the followers to follow the Prophet SAW as role model:

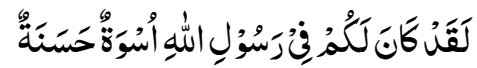

'No doubt, the Prophet of Allah has an excellent life for you people to follow $^{49}$. (Surah Al-Ahzab-33, Verse, 21)

The Quran declared the Messenger of God as the owner of high character.

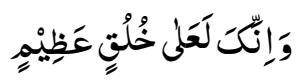

And certainly, you are placed highest on the Most Magnificent and Dignified character ${ }^{50}$ (Surah Al-Qalam, 68: 4). Also sayings of Prophet SAW:

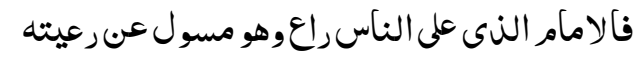

This concept of servant leadership is a Prophetic tradition and emphasizes the importance of honesty, dedication among leaders to serve their supporters $^{51}$ (Muslim, 2000).

\section{TRANSFORMATIONAL LEADERSHIP:}

Transformation leadership is embedded from powerful values. The values are firm and are reflected to be eternal. ${ }^{52}$ The approaches of Islamic

${ }^{48}$ Muslim (2000). Sahih Muslim

${ }^{49}$ Al-Quran (33): 21.

${ }^{50} \mathrm{Al}$-Quran (68): 4.

${ }^{51}$ Muslim (2000). Sahih Muslim

${ }^{52}$ Sinha, G. R. Human Values towards Eternal Happiness: Enhancing Professional Success. DOI: 10.13140/RG.2.1.2509.0641. (2013). 
The Scholar Islamic Academic Research Journal

Vol. 6, No. 2 || July -December 2020 || P. 86-109

https://doi.org/10.29370/siarj/issue11ar4

leadership are recognized by ${ }^{53}$ they are identification and articulation a vision, speed up goals, greater performance prospects, and to provide personal sustenance. This vision is expressed by Holy Prophet (SAW) to followers for making a universal civilization built on justice. Quran says:

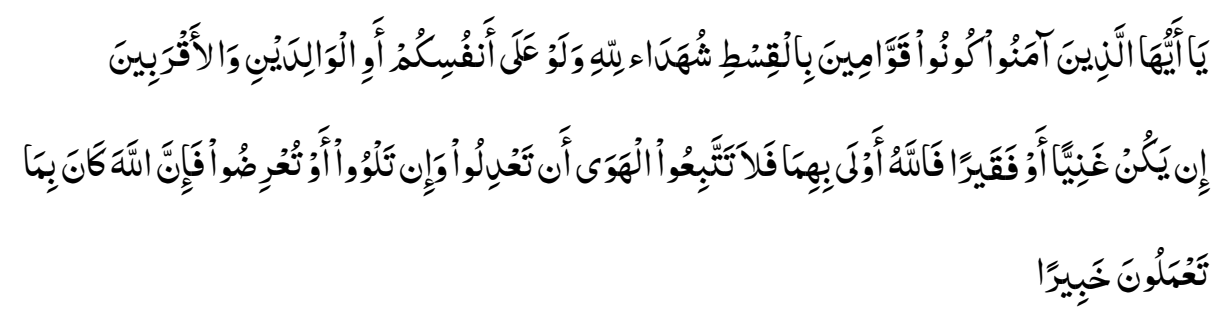

O you who believed, be obstinately standup stable in impartiality, observers for Allah, even if it contrary to yourselves or relatives or parents. Whether one is poor or rich, Allah is extra praiseworthy of both. So do not follow liking, in case you not be fair. And if you misrepresent or refused, then no doubt Allah is forever acquainted about your deeds ${ }^{54}$ (Surah An-Nisa, 4 verse, 135)

In another occasion, the Quran says:

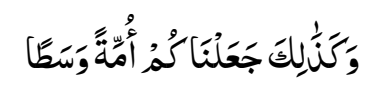

"We have prepared you a temperate nation"55 (Surah Albaqarah-2: verse143). In another occasion the Holy Quran says:

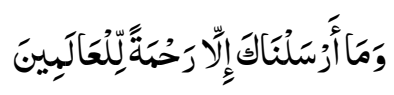

"We have not sent you but a mercy to mankind"56 (Surah Al-Anbiya-21:

\footnotetext{
${ }^{53}$ Leithwood, K., Jantzi, D., and Steinbach, R. Changing leadership for changing times. Maidenhead, Philadelphia: Open University Press. (1999).

${ }^{54}$ Al-Quran (4): 135.

${ }^{55}$ Al-Quran (2): 143.

${ }^{56}$ Al-Quran (21): 107.
} 
The Scholar Islamic Academic Research Journal

Vol. 6, No. 2 || July -December 2020 || P. 86-109

https://doi.org/10.29370/siarj/issue11ar4

verse-107). This verse is the message restated in Quran in raising recognition of joint goals ${ }^{57}$ (Abdullah et al., 2019).

\section{ETHICAL OR MORAL LEADERSHIP:}

According to ${ }^{58}$ the frame work of moral basis of leadership in Islam is voluntary submission and willingness in front of Creator. No doubt, Ihsan is a vital feature of moral accountability of Islamic leadership. ${ }^{59}$ The structure of Iman (belief of Tauheed), Islam (obedience to Allah), Taqwa (Allah's Fear), Ihsan (best deeds). It further indicated operational codes of leadership originate the strata of ethical obligation. ${ }^{60}$

\section{CHARACTERISTICS OF LEADERS:}

The Quran highlighted the vital leadership features. These contain determination, soft hearted (3:159), fairness (4:58), integrity (68:4), and wisdom $(27: 35){ }^{61}$

\section{HONESTY, INTEGRITY AND TRUSTWORTHINESS:}

An individual, who is honest, has trust, integrity, and loyalty is trusted by individuals. The Holy Quran says:

${ }^{57}$ Abdallah, et al. A review of Islamic perspectives on leadership. International Journal of Scientific Research and Management (IJSRM), 7No.11(2019): 574-578.

${ }^{58}$ Beekun, R. I. and Badawi, J. Leadership: An Islamic perspective. Beltsville, MD: Amana. (1999).

${ }^{59}$ Abdallah, et al. A review of Islamic perspectives on leadership. International Journal of Scientific Research and Management (IJSRM), 7No.11(2019): 574-578.

${ }^{60}$ Haddara, M., and Enanny, F. Leadership: An Islamic Perspective. Faculty of Education of Memorial University of Newfoundland. (2009).

${ }^{61}$ Malik, M. F. Translation of the meanings of Al-Quran. Houston, TX: The Institute of Islamic Knowledge. (1997). 
The Scholar Islamic Academic Research Journal

Vol. 6, No. 2 || July -December 2020 || P. 86-109

https://doi.org/10.29370/siarj/issue11ar4

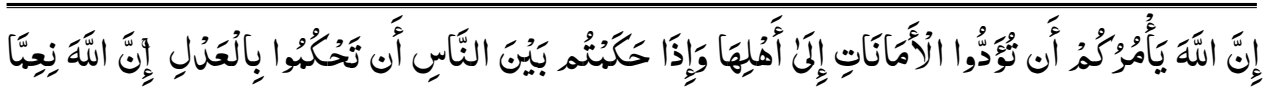

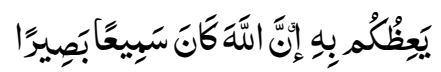

No doubt, Allah orders you to return trusts to whom they are payable and when make justice among persons decide with justice. Outstanding is that what Allah teaches you. No doubt, Allah always Hears and Sees ${ }^{62}$ (Surah An-Nisa, 4 verse, 135) $\square$

In another occasion, Allah SWT says in Quran:

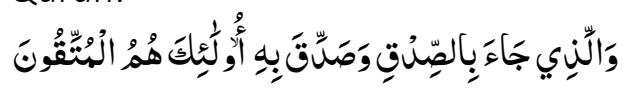

The one who carries the truth and the one who admits it as real those are righteous of Almighty Allah SWT"63 (Surah Az-Zumar-39, verse-33). Allah SWT also mention in Quran:

$$
\text { وَاِِنَكَ لَعَلى خُلُقِ عَظِيْمِ }
$$

“Truly you have a strong character."64

In another occasion, Allah Almighty says in Quran:

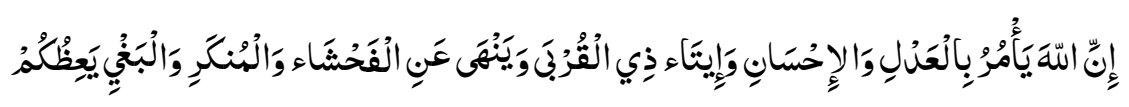

\footnotetext{
62 Al-Quran (4): 135.

${ }^{63}$ Al-Quran (39): 33.

${ }^{64}$ Al-Quran (68): 4.
} 
The Scholar Islamic Academic Research Journal

Vol. 6, No. 2 || July -December 2020 || P. 86-109

https://doi.org/10.29370/siarj/issue11ar4

No doubt, Allah commands impartiality and virtuous behavior and generous to kin and prohibits wickedness and evil behavior and cruelty. He reprimands you that maybe you will be retold. ${ }^{65}$ (Surah Al-Nahl-16, verse90).

\section{BUILDING A COMMUNITY:}

Allah Almighty mentions in the Holy Quran:

"There should be a community that invite for what is respectable, wishes what is correct,
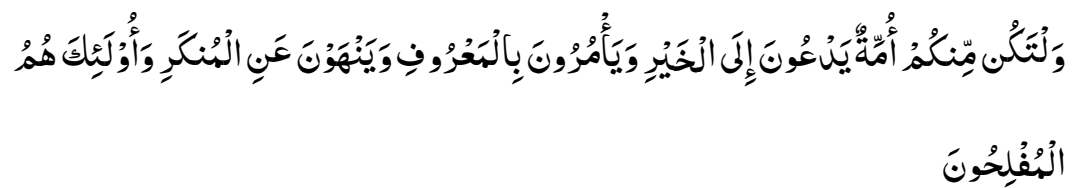

and prohibits what is incorrect: they are the successful ones." ${ }^{\prime 66}$ (Surah AlImran-3, verse-104)

\section{RESPECT AND DIGNITY OF THE INDIVIDUALS:}

The sayings of Quran and Prophet (SAW) equally stresses on worth of entire human beings. Almighty Allah says in Quran:

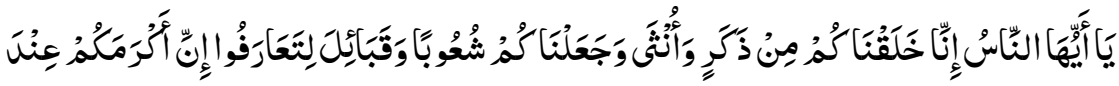

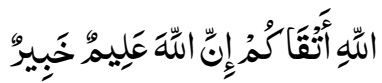

“O' People, We have made you from a single man and a single woman, and divided into tribes and races so that you may recognize each another" ${ }^{\prime 67}$ [Surah Al-Hujurat-49, verse-13]. These are the preaching of the Holy Quran that people should behave positively with each other and

65 Al-Quran (16): 90.

${ }^{66}$ Al-Quran (3): 104.

${ }^{67}$ Al-Quran (49): 13. 
esteem:

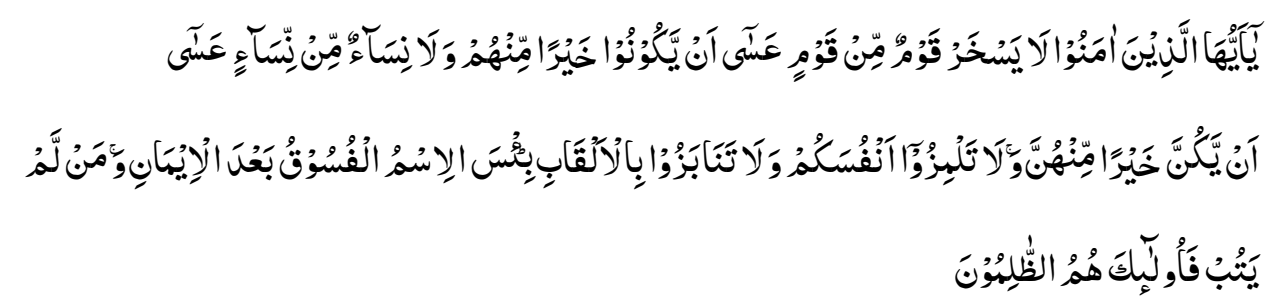

“O' Momins, neither among you men nor women should taunt at others, may be they would better than you people. And don't abuse each other and do not call them by epithets. Worthless the names of defiance after belief. And those do not regret - then those are the sinners. ${ }^{68}$ [Surah Al-Hujrat, 49, verse-11].

\section{WORKING SILENTLY}

We the Muslims should devote all our actions to Almighty Allah SWT. No need for worldly remuneration. Almighty Allah assured to remunerate these actions. These rewards may be benefitted in the hereafter. The Quran tells:

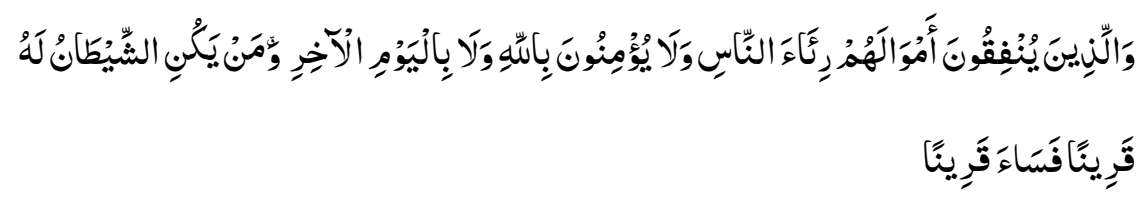

And those who devote of their capital to be perceived by the people and trust not in Allah nor in the eternal Day. And he to whom Satan is a friend then sinful is he as a friend. ${ }^{69}$ (Surah An-Nisa, verse-38).

\section{PRESENTATION OF PERFORMANCE:}

The idea of performance as mentioned by Ibn-e-Taymiah make the effective leader completed the task timely. Muslims were keen interested

${ }^{68}$ Al-Quran (49): 11.

${ }^{69}$ Al-Quran (4): 38. 
The Scholar Islamic Academic Research Journal

Vol. 6, No. 2 || July -December 2020 || P. 86-109

https://doi.org/10.29370/siarj/issue11ar4

in selecting the eligible persons for right jobs.

\section{THE FOLLOWERS:}

Consideration of followers is emphasized as vital characteristics for effective leadership in Islam. The Quran says:

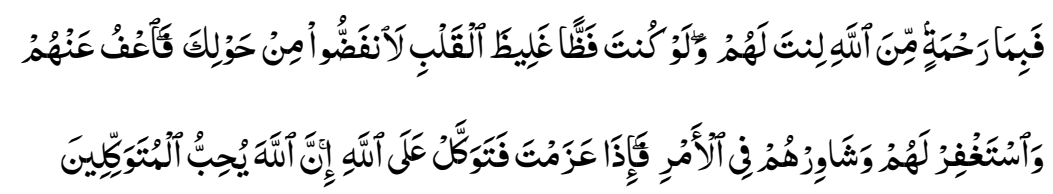

So by sympathy from Allah, [O Messenger], you remained soft with people. When you become impolite and unsympathetic, they went scattered from thou. So forgive and seek mercy for them and consult in matters. And after making decision, then trust in Allah. Definitely, Allah likes person who trusts in Him. ${ }^{70}$

PERSEVERANCE

It is revealed frequently in Quran the characteristics of followers strive to acquire knowledge. Quran acclaims to fulfil the promises, it will be asked.

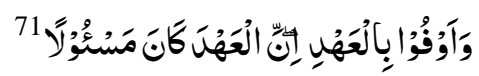

\section{A famous routine of Prophet (SAW) showed that determination is the} half Eman.

Holy Quran and the Sunnah are two main bases for Islamic leadership role. The Quran is the divine Book from Allah Almighty, and Sunnah enlightens the model character of Prophet Muhammad (SAW). The Holy Quran is universal text gifted to Muslims to find ways that are pertinent, significant, and prominent to lead the lives.

\footnotetext{
${ }^{70}$ Al-Quran (3): 159.

${ }^{71}$ Al-Quran (17): 34.
} 
Leadership is a principle that is extremely stressed in the lives of Muslims and is personified the idea of accountability72. The Prophet Muhammad (PBUH) states: 'every person among you is custodian and is accountable for his people ${ }^{73}$ (Saheeh al Bukhari: 212)

The operational philosophies of leadership are practiced by Muslim leaders comprise the execution of trust, implementation of justice, obedience of morality, perception of right and wrong, and honoring potentials. $^{74}$

The Islamic Leadership Model has four notions: Realization to almighty Allah SWT, Consultation, Competency, and Thoughtfulness. ${ }^{75}$ This leadership model is similar to the modern concepts of participative leadership which offers input from all assistants. ${ }^{76}$

THE NATURE OF LEADERSHIP IN ISLAM:

${ }^{72}$ Abdallah, et al. A review of Islamic perspectives on leadership. International Journal of Scientific Research and Management (IJSRM), 7 No.11 (2019): 574-578.

${ }^{73}$ Saheeh al Bukhari: 212

${ }^{74}$ Beekun, R. I. and Badawi, J. Leadership: An Islamic perspective. Beltsville, MD: Amana. (1999).

${ }^{75}$ Abdallah, et al. A review of Islamic perspectives on leadership. International Journal of Scientific Research and Management (IJSRM), 7No.11(2019): 574-578.

${ }^{76}$ Huang, X., Iun, J., Liu, A, \& Gong, Y. Does participative leadership enhance work performance by inducing empowerment or trust? The differential effects on managerial and non-managerial subordinates. Journal of Organizational Behavior, 31(1):122-43. (2010). 
The Islamic Leadership is based on code of trust (Amanah). The leader is desired to lead a group with accountable to both the groups and to God. To achieve this trust, man is gifted with abilities to learn at the time of creation. The Prophet Adam was nominated as vicegerent of Almighty Allah on earth and was taught accordingly. 'Remind the occasion, when thy Lord told to angels: I will create a vicegerent on earth ${ }^{, 77}$

The accountability and trust and go side by side. Islam stresses the accountability to Almighty Allah SWT and to people who are entrusted to leading. 'If a person expires while cheating the people that was commended with, he will unable to enter heaven ${ }^{78}$ (Muslim, 2000).

According to Fitzpatrick, leadership involves vibrant relationships, mutual inspiration and shared purpose between collaborators and leaders and both are motivated to higher level of moral development to exert real projected change. $^{79}$ In the recent situation, the process of leadership requires organized group and influencing achievements for common goals. ${ }^{80}$ The intelligence, determination, self-confidence, sociability and integrity are

\footnotetext{
${ }^{77}$ Surat Al-Baqrah, verse-30

${ }^{78}$ Muslim (2000). Sahih Muslim

${ }^{79}$ Fitzpatrick, B., and Collins-Sussman, B. Team Geek: A software developer's guide to working well with others. O'Reilly Media Incorporated. (2012).

${ }^{80}$ Northouse, P. G. Leadership: Theory and practice: Sage publications. 2018.
} 
prime traits linked with operational leadership in theories of modern leadership.

Leaders are considered to enforce justice and promote harmony constantly ${ }^{81}$. The Quran says: "No doubt Allah orders you to bring the faiths to your proprietors when you evaluate people, evaluate with fairness. Outstanding definitely is what Allah SWT guides you. No doubt, Allah hears all, sees all $\$ 2$ There are many directions from Quran for believers: 'O believers, Obey Allah, as well as the Messenger and persons who have authority amongst you. If you vary in whatsoever among yourselves, cite it to Almighty Allah and the Prophet, if you had confidence in Allah and Day of Judgment. This is finest, and most appropriate for ultimate willpower. ${ }^{83}$

\section{DISCUSSION:}

Leadership concept is as old as the history of this universe. Leadership is old like hills. Actually, in etymological perspective, the word leader is modern. In 1821, the word leader was combined with suffix, 'ship' means position. The term leader has an ancient pedigree derived from Deep-

\footnotetext{
${ }^{81}$ Rafiki, A. Islamic Leadership: Comparisons and Qualities. Faculty of Economics and Business, Universitas Medan Area, Medan, Indonesia. (2020).

${ }^{82} \mathrm{Al}-\mathrm{Quran}(4): 58$.

${ }^{83}$ Al-Quran (4): 59.
} 
rooted English, leadere, (who leads). Leader or lead didn't have Greek or Latin derivation. The close word for leadership in Latin 'ducere' mean to regard or consider. Latest Romanian language has 'conducer' as substitute for leadership (leadershipissues.org). There are five stages of emergence of leadership. Followership, self-leadership, leader of followers, leader of leaders, and supreme leaders. ${ }^{84}$

On the other hand, Islamic Leadership concept is as old as creation of humanity. They are called upon by Almighty Allah SWT a Vicegerent, the guardian, Imam, Khalifa. The Quran has extremely discussed the qualities of leaders in a comprehensive way.

\section{(c) $(1)(0)$} Attribution-NonCommercial-ShareAlike 4.0 International (CC BY-NC-SA 4.0)

${ }^{84}$ Denton, R. The 5 stages of leadership emergence. https://www.asianaccess.org/ (2017). 